\title{
Characterization of Subtype of Propylbenzilylcholine Mustard (PrBCM)-Sensitive and -Resistant Muscarinic Cholinoceptors in Guinea Pig Ileal Muscle
}

\author{
Mariko Harada, Katsuo Koike and Issei Takayanagi* \\ Department of Chemical Pharmacology, Toho University School of Pharmaceutical Sciences, Funabashi, Chiba 274, Japan \\ Received April 15, 1992 Accepted June 8, 1992
}

\begin{abstract}
The subtype of propylbenzilylcholine mustard (PrBCM)-sensitive and -resistant muscarinic cholinoceptors in guinea pig ileal muscle was examined using four selective muscarinic antagonists, pirenzepine, AF-DX 116, himbacine and 4-DAMP. The $\mathrm{pA}_{2}$ values of the four antagonists against pilocarpine were not different from their values against carbachol after the treatment with PrBCM and was identified with the values for the $\mathrm{m} 3$ subtype. These results suggest that the subtype of PrBCM-sensitive and -resistant muscarinic cholinoceptors in guinea pig ileal muscle is the $\mathrm{m} 3$ subtype only and not other subtypes.
\end{abstract}

Keywords: Propylbenzilylcholine mustard (PrBCM) receptor, Muscarinic m3 subtype

Muscarinic cholinoceptors have been pharmacologically divided into three major subtypes, $\mathrm{M}_{1}, \mathrm{M}_{2}$ and $\mathrm{M}_{3}$ subtypes, by differences in affinities for the selective competitive antagonists $(1-4)$. However, differing from these subclassifications based on findings obtained from functional studies using selective competitive antagonists, we have proposed that in the intestinal smooth muscles, there are two types of cholinoceptor mechanisms, one being sensitive to and the other being resistant to propylbenzilylcholine mustard ( $\operatorname{PrBCM}$ ), which is known to be an irreversible specific muscarinic cholinergic antagonist. Cholinergic partial agonists (e.g., pilocarpine) produce contractions of the intestinal smooth muscle through activation of PrBCM-sensitive receptors, while full agonists (e.g., carbachol), which contract it through an interaction with both types, are more effective at $\mathrm{PrBCM}$-resistant receptors than at PrBCM-sensitive receptors. Pilocarpine, a partial agonist, behaves as a competitive cholinergic antagonist on PrBCM-resistant receptors in the intestinal smooth muscles treated with PrBCM (5-7). Furthermore, PrBCM-sensitive cholinoceptors were found to play a physiological role (6). However, these two types may also provide clues for finding unknown subtypes.

Recently, molecular cloning of muscarinic receptors

* To whom all correspondence should be addressed. has demonstrated the presence of five related but distinct gene products $(\mathrm{m} 1, \mathrm{~m} 2, \mathrm{~m} 3, \mathrm{~m} 4$ and $\mathrm{m} 5)(8,9)$. Pharmacological studies can differentiate muscarinic receptors into three types $\left(\mathrm{M}_{1}, \mathrm{M}_{2}, \mathrm{M}_{3}\right)$, and this pharmacological classification most likely corresponds to the $\mathrm{m} 1, \mathrm{~m} 2$ and $\mathrm{m} 3$ receptors, respectively. More recently, Dörje et al. (10) have determined the affinity profiles of several of the selective muscarinic antagonists at five cloned human muscarinic receptors $(\mathrm{m} 1-\mathrm{m} 5)$ stably expressed in Chinese hamster ovary cells (CHO-K1).

In this paper, we tried to characterize PrBCM-sensitive and -resistant muscarinic cholinoceptor subtypes in guinea pig ileal muscle using four selective muscarinic antagonists: pirenzepine ( $\mathrm{m} 1\left[\mathrm{M}_{1}\right]$-selective); AF-DX 116 (11-([2-|(diethylamino)methyl|-1-piperidinyl]acetyl)-5,11-dihydro-6H-pyrido[2,3-b][1,4]benzodizepine-6-one) (m2 $\left[\mathbf{M}_{2}\right]-$ selective); himbacine $\left(\mathrm{m} 2\left[\mathrm{M}_{2}\right], \mathrm{m} 4\right.$-selective); and 4DAMP (4-diphenylacetoxy- $N$-methylpiperidine methiodide) (m1 $\left[M_{1}\right], m 3\left[M_{3}\right]$-selective).

Male guinea pigs, weighing 250 to $350 \mathrm{~g}$, were killed by a blow on the head. A longitudinal muscle strip was isolated by carefully slipping an ileal segment over a tapered glass rod. A piece (about $3 \mathrm{~cm}$ ) of the strip was suspended in a $20-\mathrm{ml}$ organ bath filled with a physiological solution of the following composition: $154 \mathrm{mM}$ $\mathrm{NaCl}, 5.6 \mathrm{mM} \mathrm{KCl}, 2.1 \mathrm{mM} \mathrm{CaCl}, 0.8 \mathrm{mM} \mathrm{MgCl}, 6.0$ $\mathrm{mM} \mathrm{NaHCO}$ and $2.8 \mathrm{mM}$ glucose, kept at $37^{\circ} \mathrm{C}$ and 
gassed with a mixture of $95 \% \mathrm{O}_{2}$ and $5 \% \mathrm{CO}_{2}$. Responses to agonists were isotonically recorded under a tension of $0.7 \mathrm{~g}$. Concentration-response curves of agonists were obtained cumulatively

To exclude the effect of muscarinic cholinoceptors, after the control concentration-response curve for carbachol were determined, the preparation was treated with $\operatorname{PrBCM}\left(3 \times 10^{-6} \mathrm{M}\right)$ for 50 min according to the method of Hisayama et al. (11). When PrBCM was applied for $50 \mathrm{~min}$, it was renewed every $10 \mathrm{~min}$. The preparation was then allowed to re-equilibrate for 30 min with washing every $10 \mathrm{~min}$. The curve for carbachol was again determined after thorough washing every $10 \mathrm{~min}$.

To estimate the dissociation constants of four competitive antagonists, the $\mathrm{pA}_{2}$ value (a negative logarithm of the dissociation constant) can be calculated by the method of Arunlakshana and Schild (12) as modified by Tallarida et al. (13). After determining the control concentration-response curves for carbachol after the treatment with PrBCM (response mediated through PrBCM-resistant muscarinic cholinoceptors) and pilocarpine (response mediated through $\operatorname{PrBCM}$-sensitive ones), the preparation was equilibrated with a competitive antagonist for $30 \mathrm{~min}$. A concentration-response curve for agonist was then obtained in the presence of the antagonist, and the procedure repeated with a high (either 3-fold or 10-fold) concentration in the same preparation. The $\mathrm{pA}_{2}$ valuc was calculated from parallel shifts of the curve for the agonist.

The data are expressed as means with S.E., and Duncan's new multiple range test was used to calculate statistical significance where appropriate. A P value less than 0.05 was considered as a significant difference. The following drugs were used: Carbachol chloride and pilocarpine hydrochloride (Sigma, St. Louis, MO); PrBCM (New England Nuclear, Boston, MA); AF-DX 116 and himbacine (Dr. Karl Thomae GmbH, Biberach, Germany); pirenzepine and 4-DAMP (Research
Biochemicals, Inc., Natick, MA).

Concentration-response curves of carbachol after a 50 -min treatment with $\operatorname{PrBCM}\left(3 \times 10^{-6} \mathrm{M}\right)$ and those of pilocarpine without $\mathrm{PrBCM}$-treatment were shifted to the right in a parallel manner by the four antagonists, pirenzepine, AF-DX 116, himbacine and 4DAMP. The $\mathrm{pA}_{2}$ values and slopes of the four antagonists are shown in Table 1. Schild plots of these results yielded a straight line with a slope of 1 (Table 1). The $\mathrm{pA}_{2}$ values of the four antagonists against pilocarpine were not different from their values against carbachol after the treatment with PrBCM (Table 1). The results suggest that the PrBCM-sensitive muscarinic cholinoceptors are of the PrBCM-resistant subtype.

It is widely known that pirenzepine has its highest affinity for $\mathrm{m} 1\left(\mathrm{M}_{1}\right)$ receptors; AF-DX 116 , for $\mathrm{m} 2$ $\left(\mathrm{M}_{2}\right)$ receptors; and 4-DAMP, for $\mathrm{m} 1\left(\mathrm{M}_{1}\right)$ and $\mathrm{m} 3$ $\left(\mathrm{M}_{3}\right)$ receptors (14). Our results suggest that the subtype of the PrBCM-sensitive and -resistant muscarinic cholinoceptors is not the $\mathrm{m} 1\left(\mathrm{M}_{1}\right)$ or $\mathrm{m} 2\left(\mathrm{M}_{2}\right)$ subtype, because pirenzepine and AF-DX 116 have low affinity (Table 1). Dörje et al. (10) reported that himbacine is a valuable tool for distinguishing $\mathrm{m} 2$ and $\mathrm{m} 4$ receptors from all other subtypes, $\mathrm{m} 1, \mathrm{~m} 3$ and $\mathrm{m} 5$. The $\mathrm{pA}_{2}$ values of himbacine against carbachol after the treatment with PrBCM and pilocarpine are $7.00 \pm 0.02$ and $7.02 \pm \mathbf{0 . 0 3}$, respectively (Table 1 ). These values are in good agreement with the $\mathrm{pKi}$ value $(7.03 \pm 0.03)$ for $\mathrm{m} 3$ receptors reported by Dörje et al. (10). However, these values are significantly different from the $\mathrm{pKi}$ values $(7.96 \pm 0.05$ and $6.31 \pm 0.05)$ for $\mathrm{m} 4$ and $\mathrm{m} 5$ receptors, respectively, reported by Dörje et al. (10). Moreover, the $\mathrm{pA}_{2}$ values of 4-DAMP support that the subtype of PrBCM-sensitive and PrBCM-resistant muscarinic cholinoceptors is the $\mathrm{m} 3$ subtype. These results suggest that the subtype of $\operatorname{PrBCM}$-sensitive and -resistant muscarinic cholinoceptors in guinea pig ileal muscle is the $m 3$ subtype and not the other subtypes, $m 1$, $\mathrm{m} 2, \mathrm{~m} 4$ and $\mathrm{m} 5$. Recently, we reported that PrBCM

Table 1. The $\mathrm{pA}_{2}$ values and slopes for four muscarinic antagonists

\begin{tabular}{lcccc}
\hline & \multicolumn{2}{l}{$\begin{array}{l}\text { PrBCM-sensitive receptors } \\
\text { (against pilocarpine) }\end{array}$} & \multicolumn{2}{l}{$\begin{array}{l}\text { PrBCM-resistant receptors } \\
\text { (against carbachol afte } \\
\text { treatment with PrBCM) }\end{array}$} \\
\cline { 2 - 6 } Antagonists & $\mathrm{pA}_{2}$ & slope & $\mathrm{pA}_{2}$ & slope \\
\hline Pirenzepine & $6.56 \pm 0.04$ & $1.00 \pm 0.12$ & $6.49 \pm 0.02$ & $0.94 \pm 0.01$ \\
AF-DX 116 & $6.45 \pm 0.04$ & $1.03 \pm 0.10$ & $6.30 \pm 0.06$ & $0.90 \pm 0.10$ \\
Himbacine & $7.02 \pm 0.03$ & $0.97 \pm 0.01$ & $7.00 \pm 0.02$ & $0.96 \pm 0.01$ \\
4-DAMP & $9.05 \pm 0.03$ & $0.96 \pm 0.01$ & $9.00 \pm 0.04$ & $0.95 \pm 0.02$ \\
\hline
\end{tabular}

Mean \pm S.E. of 6 experiments. 
differentiated the two mechanisms, PrBCM-sensitive and -resistant ones, in the presence of guanine nucleotide (GTP), but in its absence, PrBCM did not discern the two. In other words, one mechanism is PrBCMsensitive, irrespective of the presence or absence of GTP, and the other is PrBCM-resistant only when GTP is present (15). G-Protein-linked receptors and G-protein are considered to be present separately, and the receptors are activated by their binding with an agonist; the receptors and G-protein will associate to elicit a final response. However, it is now not known how GTP regulates PrBCM-sensitive and -resistant cholinoceptors. Since the subtype of muscarinic cholinoceptors in guinea pig ileal muscle is only the $\mathrm{m} 3$ subtype, PrBCM may distinguish between two states of $m 3$ with and without GTP, although further studies are needed to clarify this point.

\section{Acknowledgments}

This study was supported by a Grant-in-Aid for Scientific Research from the Ministry of Education, Science and Culture, Japan and by funds from Teijin Co., Ltd., Tokyo, Japan.

\section{REFERENCES}

1 Hammer, R., Berrie, P.C., Birdsall, N.L.M., Burgen, A.S.V. and Hulme, E.C.: Pirenzepine distinguishes between different subclasses of muscarinic receptors. Nature 283, 90-92 (1980)

2 Hammer, R., Giraldo, E., Schiavi, G.B., Monferini, E. and Ladinsky, H.: Binding profile of a novel cardioselective muscarinic receptor antagonist, AF-DX 116, to membranes of peripheral tissues and brain in the rat. Life Sci. 38, 16531662 (1986)

3 De Jonge, A., Doods, H.N., Riesbons, D. and Van Zwieten, P.A.: Heterogeneity of muscarinic binding sites in rat brain, submandibular gland and atrium. Br. J. Pharmacol. 89, 551P (1986)

4 Doods, H.N., Mathy, M.J., Davidesko, D., Van Carldorp, K.L., De Jonge, A. and Van Zwieten, P.A.: Selectivity of muscarinic antagonists in radioligand and in vivo experiments for putative $\mathbf{M}_{1}, \mathbf{M}_{2}$ and $\mathbf{M}_{3}$ receptors. J. Pharmacol. Exp. Ther. 242, 257-262 (1987)

5 Takayanagi, I., Kiuchi, Y., Ohtsuki, H. and Harada, M. Activation of propylbenzilylcholine mustard-sensitive muscarinic cholinoceptors more effectively utilizes cytosolic $\mathrm{Ca}^{21}$ for contraction in guinea-pig intestinal smooth muscle. Eur. J. Pharmacol. 187, 139-142 (1990)

6 Takayanagi, I., Harada, M. and Koike, K.: A difference in receptor mechanisms for muscarinic full and partial agonists. Japan. J. Pharmacol. 56, 23-31 (1991)

7 Takayanagi, I., Ohtsuki, H., Saito, K., Koike, K. and Satoh, M.: Propylbenzilylcholine mustard ( $P r B C M$ )-sensitive cholinoceptors and contractile response to partial agonist in guinea pig ileal muscle. Japan. J. Pharmacol. 56, $151-158$ (1991)

8 Bonner, T.I., Buckley, N.J., Young, A.C. and Brann, M.R.: Identification of a family of muscarinic acetylcholine receptor genes. Science 237, 527-532 (1987)

9 Fukuda, K., Kubo, T., Maeda, A., Akiba, I., Bujo, H., Nakai, J., Mishina, M., Higashida, H., Neher, E., Marty, A. and Numa, S.: Selective effector coupling of muscarinic acetylcholine receptor subtypes. Trends Pharmacol. Sci. 10, Supp. 4-10 (1989)

10 Dörje, F., Wess, J., Lambrecht, G., Tacke, R., Mutschler, E. and Brann, M.R.: Antagonist binding profiles of five cloned human muscarinic receptor subtypes. J. Pharmacol Exp. Ther. 256, $727-733$ (1991)

11 Hisayama, T., Kumagai, N. and Takayanagi, I.: Two apparently distinct muscarinic cholinoceptor mechanisms in guinea-pig taenia caecum. Japan. J. Pharmacol. 46, 414-416 (1988)

12 Arunlakshana, O. and Schild, H.O.: Some quantitative uses of drug antagonist. Br. J. Pharmacol. 14, 48-58 (1959)

13 Tallarida, R.J., Cowan, A. and Adler, M.W.: $\mathbf{p A}_{2}$ and receptor differentiation: a statistical analysis of competitive antagonism. Lifc Sci. 25, 637-654 (1979)

14 Hulme, E.C., Birdsall, N.J.M. and Buckley, N.J.: Muscarinic receptor subtypes. Annu. Rev. Pharmacol. Toxicol. 30, 633$673(1990)$

15 Kiuchi, Y., Kumagai, N., Hisayama, T. and Takayanagi, I.: Guanosine 5'-triphosphate converts some populations of propylbenzilylcholine mustard-sensitive muscarinic cholinoceptor sites to sites resistant to the drug in intestinal smooth muscle. Japan. J. Pharmacol. 55, $329-338$ (1991) 